\title{
AUTHOR INDEX VOLUME 13 (1995)
}

(The issue number is given in front of the page numbers)

Blake, V.L.P. and R. Tjoumas, Through the looking glass darkly: research agendas and faculty attitudes regarding periodical prestige

Bruce, H., Internet and academic teaching in Australia

(2) $103-115$

Burrows, T., Educating for the Internet in an academic library: the Scholar's Centre at the University of Western Australia

Cochrane, C., Learning to use a graphics presentation package: the complexity of an undergraduate learning task

(3) $229-242$

Clark, A.J., Education and training for librarianship and information work: Annual bibliography, 1994

Currás, E., Professional and user training in the science faculty of the Universidad Autónoma de Madrid (Short Communication)

Easton, E., see D. Oberg

Elkin, J., see T.D. Wilson

Evans, J. and R. Raddon, Teacher-Librarianship training in Papua New Guinea - development through a link scheme

Farah, B.N. and M.A. Higby, Students' perception of teaching formats and teaching aids

Fowell, S.P. and P. Levy, Computer-mediated communication in the information curriculum: an initiative in computer-supported collaborative learning

(2) $131-143$

(4) $261-331$

(4) $361-368$

(2) $117-129$

(1) $57-62$

(1) $41-50$

(4) $349-359$

Fülöp, G., The TEMPUS-connection of the Department for Library and Information Sciences of the Eötvös Loránd University Budapest

(3) $193-210$

Guy, F., 18th International Online Information Meeting Olympia 2, London, England, 6-8 December 1994 (Short Communication)

(1) $35-40$

Harvard-Williams, P., Consortium of African Schools of Information Sciene (Short Communication)

(1) 63- 65

Head, M.C. and R. Marcella, Teaching "reference work" in Aberdeen: a personal perspective (News from the Schools)

(1) $51-52$

Higby, M.A., see B.N. Farah

(1) $67-71$

Kirk, J., see R.J. Todd

(4) $349-359$

Levy, P., see S.P. Fowell

(4) $333-347$

(3) $193-210$

Marcella, R., see M.C. Head

(1) $67-71$

Moahi, K., see R. Neill

(1) $1-20$

Morris, A., see G. Sargent

(2) $91-102$

0167-8329/95/\$03.50 @ 1995 - IOS Press 
Neill, R. and K. Moahi, Strategic change. A case study of the Department of Library and Information Studies at the University of Botswana

Oberg, D. and E. Easton, Focus group interviews: A tool for program evaluation in school library education

(2) $117-129$

Raddon, R., see J. Evans

(1) $41-50$

Sargent, G. and A. Morris, Practical implications of the introduction of flexible learning techniques to an IT-based course

(2) $91-102$

Schmidt, R. and S. Werther, Birth of a new degree programme in Europe: Media Documentation, a course of study at the Fachhochschule of Hamburg, Germany

(2) $145-154$

Shade, L.R., Wired in the ivory tower: access and copyright issues surrounding the Internet and higher education in North America

(3) $211-228$ Silva, M., The process of introducing Internet-based classroom projects and the role of school librarians

(3) $243-252$

Stilwell, C. and C. Vietzen, Improving education for library and information work: the simulated fieldwork practicum at the University of Natal

Tjoumas, R., see V.L.P. Blake

(1) 21- 34

Todd, R.J. and J. Kirk, Concept mapping in information science

(2) $103-115$

Vietzen, C., see C. Stilwell

(4) $333-347$

(1) 21- 34

Werther, S., see R. Schmidt

(2) $145-154$

Wilson, T.D. and J. Elkin, Review of the work of Bailer HoDS Committee (Short Communication)

(1) $57-62$

Wilson, T., Education for Information and the Internet, Guest Editorial

(3) $171-175$ 